\title{
A Critique and Discussion of the View That Shi Miyuan Proposed the Five-Mountain, Ten-Monastery System
}

\author{
LAN Jih-chang*
}

\begin{abstract}
When Japan, during the Kamakura (1180-1333) and Muromachi (1336-1573) periods, imported Zen 禪 Buddhism from Song (960-1279) and Yuan (12791368) China, it not only continually dispatched Zen monks on pilgrimages to China to seek materials for transmitting sectarian doctrine, but also introduced Zen temple architecture and monastic discipline to Japan, established the Five Mountain, Ten Monastery 五山十刹 system of government temples, and developed Five Mountain 五山 literature. This system of government temples is believed to have imitated the Song system of government temples of the same name. Moreover, it is the best example of Sino-Japanese cultural interaction in the field of Buddhism.

In contrast with the ample materials we have on the operation of the Japanese system of the Five Mountain, Ten Monastery government temples, we lack sufficient materials to determine the time and impetus of the Song system of Five Mountain, Ten Monastery government temples and are at a loss to give a detailed accurate account of the Song system. Among the many views in circulation, the view most accepted by modern scholars is that Shi Miyuan 史爾遠 proposed to the court to establish this system of government temples during the reign of Emperor Ningzong (r. 1194-1224) of the Southern Song dynasty. But this theory comes down to us from Song Lian 宋濂 (1310-1381) of the early Ming dynasty, and no Song or Yuan sources mention this matter. Moreover, no Japanese Five Mountain Zen monks touch on this matter in any of their writings. Hence, whether Shi Miyuan actually proposed this system of government temples is a topic worth revisiting.

This paper discusses whether Shi Miyuan proposed the Five Mountain, Ten Monastery system from the vantage point of materials related to Shi Miyuan and observations of Japanese Zen monks, and it reaches the conclusion that it is not credible that Shi Miyuan proposed the system to the court.
\end{abstract}

Key words: Shi Miyuan, Five Mountains and Ten Monasteries, system of appointing abbots, government temples

* Faculty of the College of General Education, Hungkuang University, Taiwan 


\section{Introduction}

When the shogun Ashikaga Yoshimitsu 足利義滿 (1358-1408) visited Tōji Temple in Kyoto in 1382, he met with the monk Gidō Shūshin 義堂周信 (1325-1385) and asked about the establishment of the Five Mountains and Ten Monasteries of Kyoto. Shūshin said that they were established by the previous shogun. He added that the Five Mountains were, in order of precedence, first, Kenchō Temple 建長寺 in Kamakura and Nanzen Temple 南禪寺 in Kyoto; second, Engaku Temple 圓覺寺 in Kamakura and Tenryū Temple 天 龍寺 in Kyoto; third, Jufuku Temple 壽福寺 in Kamakura; fourth, Kennin Temple 建仁寺 in Kyoto; fifth, Tōfuku Temple 東福寺 in Kyoto; and that later Jōchi Temple 淨智寺 and Jōmyō Temple 淨妙寺 in Kamakura and Manju Temple 萬壽寺 in Kyoto were added to the ranking to give Kamakura and Kyoto each five temples designated as Five Mountain temples. Yoshimitsu then asked whether China also had Five Mountains and Ten Monasteries. Shūshin replied that Japan's Five Mountain, Ten Monastery system was copied from China, and that China's Five Mountains were, in order, Jingshan Temple 徑山寺, Lingyin Temple 靈隱寺, Tiantong Temple 天童寺, Jingci Temple 淨慈寺, and Ayuwang Temple 阿育王寺. ${ }^{1}$ Later in 1386, when Yoshimitsu met Shūshin in Shōkoku Temple 相國寺 in Kyoto, he asked about making Shōkoku Temple, his family temple, into the sixth mountain on par with the Five Mountains. Shūshin replied that ever since the days of the Song dynasty, there have been only Five Mountains, and that the term "Six Mountains" would be unheard of. But during the Yuan dynasty, he said, Dalongxiang Jiqing Temple 大龍翔集慶寺 in Nanjing was placed over the Five Mountains. Hence, he suggested elevating the status of Nanzen Temple above the Five Mountains and making Shōkoku Temple one of the Five Mountains. This would certainly be acceptable. ${ }^{2}$ From that point on, the five temples serving as the Five Mountains in Kamakura and the five temples serving as the Five Mountains in Kyoto remained fixed, with each Five Mountain

1 See Gidō Shūshin, Kūge nichiyō kufū ryakushū 空華日用工夫略集 (A Short Collection of Kūge's Daily Thoughts), in vol.3 of Zoku shiseki shüran 續史籍 集覧, ed. Kondō Heijō 近藤瓶城 (Tokyo: Chikafuji Shuppanbu, 1930), vol.3, p. 58. See also Kageki Hideo 蔭木英雄, Kunchū Küge nichiyō kufū ryakushū: Chūsei zensō no seikatsu to bungaku 訓注空華日用工夫略集：中世禅僧の生活と 文学 (An Annotated Edition of A Short Collection of Küge's Daily Thoughts: The Lifestyle and Literature of Medieval Zen Monks) (Kyoto: Shibunkaku Shuppan, 1982), p. 272.

2 Gidō Shūshin, Kūge nichiyō kufū ryakushū, vol.4, p. 16. Yoshimitsu built the Shōkoku Temple as the final resting place of Hino Nobuko 日野宣子, the wife of his wife's uncle. Thus did Yoshimitsu come to know about the Zen sect. For the details of this story, see Imaeda 2001, pp.471-482. 
temple serving as the head of a nexus of local temples, the whole forming a huge Buddhist network.

The military governments of the Kamakura and Muromachi bakufu 幕府 assiduously introduced Chan (= Japanese Zen, 禪) Buddhism from China: Japanese Zen monks continuously went on pilgrimages to China to study Chan Buddhism, some at the foot of a high-ranking priest, others by engaging in the affairs of a temple. They copied the architecture style of Chinese Five Mountain temples. And they took notes on the preaching and rituals of the temple, which they brought back to Japan for reference. The Japanese thus gradually built the Five Mountain, Ten Monastery system of government temples. The process by which Japan imported this system quintessentially characterizes Sino-Japanese cultural interaction during the Song and Yuan periods.

The Japanese Five Mountain, Ten Monastery system began imitating the Chinese system in the Song period, and the Song Five Mountain, Ten Monastery system was said to originate when Shi Miyuan (1164-1233) proposed such a system to the Southern Song court. Song Lian (1310-1381), in volume 2, "Inscription for the Stupa in Which Gufengde, Abbot and Chan Master of the Jingci Temple, Was Interred” 住持淨慈禪師孤峰德公塔銘, in his Record of Protecting the Law, wrote,

In the past, each abbot would take his seat and preach the law, so that there might be compassion in benefits conferred. There was never any ranking associated with the seating. In the Song period, Shi, Prince of Wei, petitioned the throne to establish a system of Five Mountains and Ten Monasteries, like what commoners call government agencies. Those who serve in these government temples must follow the discipline of a small monastery and wait until their good reputations are apparent. Then they will be promoted step by step, up as far as the famous Five Mountains, much like a government official might become a general or minister. Thus, human compassion might flourish, so that nothing can be added thereto. Ecclesiastics and laity often admire such compassion, but unless one enters the priesthood and removes oneself far from the web of ordinary relations, such compassion is not easy to attain. ${ }^{3}$

This passage mentions several key points: The first is that Shi Miyuan proposed to the court the Five Mountain, Ten Monastery system of govern-

3 Jiaxing Edition of the Tripitaka 嘉興藏, vol.21, p.623. Throughout I use the Web edition of the Jiaxing Edition of the Tripitaka and the Taisho Revised Tripitaka 大正藏, found on the website of the Chinese Buddhist Electronic Text Association 中華電子佛典協會, http://www.cbeta.org/cd/index.htm. 
ment temples. The second is that the Five Mountains and Ten Monasteries were to be like government agencies and serving in the Five Mountains and Ten Monasteries was like being a bureaucrat — one had to undergo rigorous examination. The third is that to be an abbot, one had first to serve in a small monastery, be examined and promoted to a large monastery, and eventually be promoted to the abbotship of one of the Five Mountains. The process was much like a Confucian student's serving as a government official and eventually becoming a general or minister. Just as being a general or minister was the highest attainment for a government official, so being the abbot of one of the Five Mountains was the highest attainment for a monk. Unless one excelled above the ordinary run of monks, one could hardly attain the level of an abbot at one of the Five Mountains and Ten Monasteries.

The theory that Shi Miyuan proposed the Five Mountain, Ten Monastery system became received opinion after the beginning of the Ming period (1368-1644), and over the last hundred years, scholars who discuss the Five Mountains and Ten Monasteries all assume this theory as the basis of their views. But in another work, "Inscription for the Stupa in Which Jueyuan, the Fourth Chan Master of the Tianjie Temple, Was Interred" 天界善世禪寺第四代 覺原禪師遺衣塔銘序, in volume 1 of his Record of Protecting the Law, Song Lian wrote,

The according of stupas to the good was not settled practice in the Sui and Tang dynasties. Monks simply followed the discipline of the monastery. Even in the Song dynasty, when grand temples flourished, monasteries were still not ranked hierarchically. Just the large monastery in the capital was made the head of all the other monasteries. Only after the Song capital was moved south was the system of the Five Mountains and Ten Monasteries instituted south of the Chang River, and were monks elevated on the basis of qualifications. And yet the monasteries at Huangmei and Caoxi were not included among them. Hence, Chan monasteries increasingly departed from the past. ${ }^{4}$

There is a gap of over seventy years from when the Southern Song instituted the Five Mountain, Ten Monastery system to when Shi Miyuan proposed the Five Mountain, Ten Monastery system. Song Lian, in his memorial inscriptions for two Chan masters, has this much of a time discrepancy in what he writes. Was he unaware of the discrepancy?

One does not encounter mention of Shi Miyuan's proposal of the Five Mountain, Ten Monastery system in any official records of the Song or Yuan dynasties, nor in any biographies or collected works of Chan monks, not even

4 Jiaxing Edition of the Tripitaka, vol.21, p. 601. 
in the collected works of Japanese Five Mountain Zen monks. Mujaku Dōchū 無著道忠 (1653-1745), in “Distinctions, the Five Mountains”區界 ·五山 (in Notes on the Manifestations of Zen), quoted from "Inscription for the Stupa in Which Jueyuan, the Fourth Chan Master of the Tianjie Temple, Was Interred," but clearly omits any mention of the "Inscription for the Stupa in Which Gufengde, Abbot and Chan Master of the Jingci Temple, Was Interred." Mujaku Dōchū, it appears, did not regard the view that Shi Miyuan proposed the Five Mountain, Ten Monastery system as credible.

Most modern scholars who discuss the Chinese and Japanese Five Mountain, Ten Monastery systems accept the theory that Shi Miyuan proposed the system. Indeed, this theory serves as the beginning of discussion of this topic. Yet from the Song to the Qing dynasty, Chinese and Japanese scholars and Chan and Zen monks held the opposite view. In this essay I wish to discuss whether the view that Shi Miyuan proposed the system is credible.

\section{Shi Miyuan's Connection with Buddhism}

Shi Miyuan's career in politics spanned the reigns of the Southern Song emperors Ningzong 寧宗 (r. 1194-1224) and Lizong 理宗 (r. 1224-1264), and he came to power in 1208. At first he served as Vice Director in the Ministry of Rites. The grand councilor at the time, Han Tuozhou 韓伦胄 (1152-1207), instigated a war with the Jin state in 1206, a war that ended in defeat. A year later, at Emperor Ningzong's suggestion, Shi Miyuan plotted to kill Han Tuozhou, and in 1208 he himself became grand councilor. This was Shi Miyuan's first step on the road to power. In 1224 Emperor Ningzong fell critically ill, whereupon Shi Miyuan placed Lizong on the throne and killed the Prince of Ji 濟王, the heir designated by Emperor Ningzong. He retained political control up until his death in 1233. If Shi Miyuan had indeed proposed the Five Mountain, Ten Monastery system, he must have done so between 1208 and 1224 .

Song Lian did not indicate whether Shi Miyuan proposed the Five Mountain, Ten Monastery system to the court of Emperor Ningzong or that of Emperor Lizong, but Tian Rucheng 田汝成 (1503-1557), in volume 3 of his West Lake Excursions 西湖遊覽志, wrote that the Five Mountain system was established in 1220 during the reign of Emperor Ningzong. Hence, scholars maintain that this system was instituted during the reign of Emperor Ningzong, mainly because Emperor Lizong revered Neo-Confucianism, and because soon after Emperor Lizong's death, Southern Song was conquered by the Mongols. The timeframe was too short, and the political situation at court too chaotic, for the Five Mountain, Ten Monastery system to be established during the reign of Emperor Lizong. Because the timeframe is inappropriate 
and the bits of evidence one can adduce too few, scholars do not think that the Five Mountain, Ten Monastery system was instituted during the reign of Emperor Lizong. That leaves the reign of Emperor Ningzong and the period from 1208 to 1224 as the most reasonable timeframe. From Shi Miyuan's rise to power (1208) to the fall of the Southern Song dynasty (1279) is a period of more than seventy years. It ought to be possible to find materials on the operation of the Five Mountain, Ten Monastery system during this timeframe. Hence, even though materials are scarce on the establishment of the Five Mountain system of government temples, most scholars think that it was during the Jiading era (1208-1224) of Emperor Ningzong's reign that Shi Miyuan proposed and established this system. ${ }^{5}$

In addition, scholars are also led to affirm the theory that Shi Miyuan proposed the Five Mountain, Ten Monastery system by the connection that Shi Miyuan's family had with Buddhism. Zongiian 宗鑑, in “Zhilian” 智連, volume 7 of his The Orthodox Lineage of the Buddhist Tradition 釋門正統 (ca. 1237), wrote that when Zhilian was the abbot of Yanqing Temple 延慶寺, a high-ranking official once came to discuss the Chan discipline. ${ }^{6}$ This official, according to Zhipan 志磐 in A Chronicle of the Patriarchs of Buddhism 佛祖 統紀 (1269), volume 16, was Shi Miyuan's father, who, while living in the countryside, practiced Chan Buddhism and also discussed Chan discipline and debated the import of the Garland Sutra 華嚴經 and the Sutra on the Perfection of Wisdom 般若經. Moreover, Zhilian, after he passed away, was said to be reincarnated as Shi Miyuan, ${ }^{7}$ and for a while, monks at the time regarded the belief that Shi Miyuan was the reincarnation of Zhilian as a beautiful story. After Shi Miyuan passed away, Chan Master Shitian Faxun 石 田法薰 (1171-1245) made an offering to his soul. ${ }^{8}$

Moreover, Shi Miyuan's family were members of the educated elite of Ningbo and maintained good relations with Chan and Tiantai-learning 天台學 monks. Yanqing Temple, in present-day Ningbo, was ranked in the Ming dynasty as the second best of the teaching-monastery Five Mountains 教院五 山, ${ }^{9}$ and was also the temple where Siming Zhili 四明知禮 (960-1028) developed Tiantai learning. Both The Orthodox Lineage of the Buddhist Tradition and A Chronicle of the Patriarchs of Buddhism were collections of biographies of monks written and edited by Tiantai-learning monks, and they eval-

5 Ishii 1987, p. 396.

6 The Buddhist Canon, Continued 續藏經, vol.75, p. 343.

7 Taishō Revised Tripitaka, vol.49, p. 231.

8 The Buddhist Canon, Continued, vol. 70, p. 354a. On the connection of Shi Miyuan's family with Buddhism, also see Ishii 1987, pp.395-399.

9 For changes in the ranking of Yanqing Temple, see Noguchi 2005, p. 277. 
uate Shi Miyuan quite positively. And yet in every passage concerning Shi Miyuan's dealings with the monks, there is no mention of the Five Mountain, Ten Monastery system.

In addition, the late Song lyricist Zhou Mi 周密 (1232-1298), in his Miscellaneous Observations from Guixin Street 癸辛雜識, includes several lyric poems about Shi Miyuan's family. For example, volume 1 of the supplementary collection includes “An Appreciation of Shi Hao" 史浩傳贊, and volume 2 includes "The Prince of Wei [Shi Miyuan] Appreciates the Famous Vessel” 衛王惜名器, “The Career of Shi Songzhi” 史嵩之始末, “The Revenge of Songzhi” 嵩之起復, and “Shi Zhaizhi” 史宅之. Shi Hao (11061194) was Shi Miyuan's father, Shi Zhaizhi (1205-1249) was his son, and Shi Songzhi (1189-1257) was his nephew. These lyric poems give a straightforward appraisal of members of Shi Miyuan's family, but Zhou Mi said not a word about any proposal to establish a Five Mountain, Ten Monastery system, an event too considerable to overlook.

The greatest difficulty in discussing when the Five Mountain system of government temples was established is that materials are scarce, that the Song literature seldom mentions the Five Mountain government temples. According to what we know at present, the earliest use of the term "Five Mountains" was by the Southern Song scholar Lin Xiyi 林希逸 (1193-1271), who, in "Inscription for the Stupa in Which the Former Abbot of Tianzhu Temple and Monastery Monk Was Interred” 前天竺住持同㟟法師塔銘 (volume 21 of Zhuxi Yanzhai ji shiyi gao xuji), wrote, “Qiantang 錢塘 went to Tianzhu Temple 天 筑寺, the head of all teaching temples. Monks of this temple were held in esteem comparable to that of monks of Shuangjing 雙徑 of the Five Mountains."10 By function, temples in the Song period were divided into meditation temples 禪寺, teaching temples 教寺, and discipline temples 律寺. This passage is saying that Qiantang entered Tianzhu Temple, the head of all teaching temples. Its rank was like that of Jingshan Temple 徑山寺, the head of the Five Mountain meditation temples. Jingshan Temple was also called Jingwu 徑塢. Hence it also had the name Shuangjing 雙徑. Lin Xiyi was a presented scholar during the reign of Lizong of the Southern Song. Thus, his statement indicates that during the reign of Lizong, temples and monasteries in the Southern Song period were already grouped as meditation-temple Five Mountains 禪寺五山 and teaching-temple Five Mountains 教寺五山, but he did not indicate which were the other four temples of the meditation-temple Five

10 Wenyuange 文淵閣 copy of the Siku quanshu 四庫全書 (Complete Library of the Four Branches of Literature) (photographic reproduction, Taipei: Taiwan Shangwuyin Shuguan, 1986), vol. 1185, no. 124 in the collections section, p. 765. 
Mountains or specify why there were Five Mountains for both meditation temples and teaching temples.

Records from the Song period on the Five Mountain government temples are exceeding rare. Only in the Yuan period do records start listing the temples in the Five Mountain, Ten Monastery system. For example, Cheng Tinggui 成廷珪 (fl. 1338), in “To Siming Mengtang” 寄四明夢堂哥禪師兼簡用 堂上人 (volume 3 of The Poems of Cheng Tinggui 居竹軒詩集), wrote,

The Five Mountains and Ten Monasteries are luxuriant, high, and precipitous.

And I really love my brook-side hut, hidden in the foliage.

The old disciples of Huaihai now have an opportunity.

For an itinerant revered monk is a rare sight nowadays.

No one talks about Maonü escaping civil strife or officials sounding out the complaints of the people.

One only sees Japanese monks inquiring about the Buddhist law.

I talk with Mr. Geng, and we fondly recollect together.

With white clouds in a blue sky throughout the day, what is there to worry about? ${ }^{11}$

This poem indicates that Japanese monks who went to China to meditate and study had to have the Five Mountains and Ten Monasteries on their itinerary.

In addition, Xie Yingfang 謝應芳 (1295-1392) of the Yuan dynasty, in “Mourning Rigong, Head of Dalin Monastery” 悼大林荑主日公 (volume 17 of Turtle Nest Compositions 龜巢稿), wrote,

The peak of Mt. Xiong'er has a returning guest.

We meet again, wearing the old meditation robes.

The Five Mountains and Ten Monasteries all spread the word.

No one hastens the lingering clouds to fly away from the lofty pinnacle. 12

From these two examples, one can see "Five Mountains" and "Ten Monasteries" being combined into a set phrase, but examples of the use of "Five Mountains and Ten Monasteries" are still quite rare.

From these limited materials, we can draw the following inferences: References to the Five Mountains began during the reign of Emperor Lizong (r. 1224-1264) of the Southern Song dynasty, or possibly as early as the reign

11 Wenyuange copy of the Siku quanshu, vol.1216, no. 155 in the belles lettres section, p. 333.

12 Wenyuange copy of the Siku quanshu, vol.1218, no. 157 in the belles lettres section, p. 421. 
of the Emperor Ningzong (r.1194-1224). From Lin Xiyi's inscription, we can infer that meditation temples and teaching temples in the Five Mountain system of government temples appeared at the same time, but only in the Yuan dynasty did people start referring to the Five Mountains and Ten Monasteries together. Even if Song Lian's statement were true that Shi Miyuan proposed the Five Mountain, Ten Monastery system, he could not have proposed the Five Mountains and the Ten Monasteries together.

\section{Government Temples Were Not Government Agencies, and Monks Were Not Bureaucrats}

The view that Shi Miyuan proposed the Five Mountain system of government temples includes the notion that government temples became government agencies and that the monks became bureaucrats. In one of his writings, Song Lian mentions that monks must first serve in small monasteries and gradually be promoted to larger monasteries, with the Five Mountain government temples being the culmination of their careers, just like bureaucrats working in government agencies.

In the Song dynasty, temples varied in the manner in which they selected their abbots. Some openly elected their abbots. Some relied on recommendations to appoint their abbots. Some brought in their abbots from the outside. Some selected their abbots by secret ballots. For some temples, the government appointed abbots. The Five Mountain government temples all had their abbots appointed by the government. Scholars believe that government temples were equivalent to government agencies, that the monks in government temples were just like bureaucrats, and that the government appointed outstanding monks in the government temples to be abbots. This is the reason that scholars cite Song Lian's inscription. However, the appointment system was used for all Song government temples. It was one way in which the government controlled temples and monasteries. It was not an outcome of the government's viewing them as government agencies. If the appointment system were an indication that temples and monasteries had become government agencies, the system should have already appeared during the Northern Song period (960-1127). The reign of Southern Song Emperor Ningzong (r. 1194-1224) is rather late in the game to consider making the Five Mountain government temples into government agencies.

For a monk, after leaving the secular world, first to cultivate himself in a local temple, then to move around until reaching a metropolitan temple, and finally to move to a major temple near the central government seems like the natural order of things. But except for a few well-known ecclesiastics who could exercise their talents as the abbot of a large or first-rate temple, most monks ended up in local temples. In fact, absent the recommendation of a 
powerful backer, it was difficult to enter a large temple and become its abbot. Though one can find examples of monks who gradually moved from small temples to the Ten Monasteries and later became the abbot of a Five Mountain government temple, such examples were rare, too rare to form the basis of expectations for the progression of a monastic career.

In addition to general activities, the most important obligations of monks at government temples during the Song dynasty were praying for the wellbeing of the imperial family, carrying out intercessions by an assembly of monks in response to natural disasters, burning incense and praying, and praying for the imperial family prior to engaging in group meditation. In fact, the regulations for monks during the Song and Yuan dynasties even specified the formulas and wording for prayers for the imperial family. These activities were monks' regular functions, and they were not limited to the Five Mountain government temples. To take these activities as indicating that monks were bureaucratized is an exaggeration of the facts.

Classified Regulations and Laws to the Qingyuan Era 慶元條法事類, completed in 1202, was a record of the laws and regulations from the beginning of the Southern Song (1127) to the Qingyuan era (1195-1200). Two volumes of this work are devoted to policies regulating monastic life. Covered in great detail are the proper way to test the sutras, how to obtain a permit to enter monastic life, passports for travel, and the duties of the abbot. ${ }^{13}$ Yet throughout these two volumes, there is no mention of standards for evaluating abbots; much less is there any basis for asserting that government temples became government agencies and that monks became bureaucrats.

From the Six Dynasties period (222-589) on, there were organizations of monk officials managing the affairs of monastic discipline. Though monk officials are equivalent to government officials, they have never been included in the lists of officials in the history books. Among organizations of monk officials, the closest thing to government agencies was the Commission for Buddhist and Tibetan Affairs 宣政院 during the Yuan dynasty. ${ }^{14}$ The Yuan court instituted the commission to manage affairs relating to monks and nuns,

13 Classified Regulations and Laws to the Qingyuan Period 慶元條法事類 originally consisted of 80 volumes, of which only 36 remain. Volumes 51 and 52 are titled Daoism and Buddhism 道釋門. Volume 50 covers the maintenance and transmission of doctrine, confines for testing the sutras, monastic names and tonsures, monk ordination, and abbots, and gives illuminating references. Volume 51 covers traveling, presenting registers of monks to the government, oaths, death, and miscellaneous transgressions, and gives illuminating references.

14 See Song Lian 1976, p. 2193. 
and although the monks on the commission were equivalent to officials, there were both ordained and lay commissioners working together on the commission, and none of them had high positions. Nonetheless, government temples in general were not equivalent to government agencies, nor were the monks serving at such temples ever regarded as public servants, nor did the lists of officials in the history books reserve any space for notable ecclesiastics.

During the reign of the Hongwu emperor (r. 1368-1398) of the Ming dynasty, Jiqing Temple in Dalongxiang was renamed Tianjie Chan Temple 天 界禪寺, and it was given a lintel tablet recognizing it as "the best Chan gathering in the empire." To manage monastic life in a systematic way, the government established a Buddhist Bureau 善世院 within the Tianjie Chan Temple and set up a Central Buddhist Registry 僧錄司, and in the registry it established departments and divided duties in order to systematically manage the monks and nuns of the entire nation. ${ }^{15}$ Talented monks took up positions within the bureau, and such monks were indeed the equivalent of bureaucrats. Indeed, the Hongwu emperor even treated these monks as bureaucrats, for they engaged in diplomatic missions with countries where Buddhism was highly regarded. The Hongwu emperor thus gave such monks important duties when it served his purposes. ${ }^{16}$ For example, in 1372 Zhongyou Zuchan 仲奠祖閵 and Wuyi Keqin 無逸克勤 (1321-1397) were sent on a diplomatic mission to Japan. ${ }^{17}$ While they were there, Ashikaga Yoshimitsu wanted these two Chan masters to transmit Buddhist doctrines to Japan, and he invited them to serve as abbots at Tenryū Temple. They refused, saying that they dared not remain in Japan to propagate Buddhist doctrines in Japan without the Ming emperor's permission. Chan monks of the Ming dynasty, compared with those of the Song and Yuan dynasties, were notably more bureaucratized, and their sense of mission for promoting culture abroad was considerably diminished. ${ }^{18}$

15 Song Lian, in "Sending Off Chan Master Juechu on His Way to the Lower Chang River” 送覺初禪師還江心序 (vol. 8 of his Record of Protecting the Law), wrote that the Buddhist Bureau established the positions of director 統領, associate director 副統領, educational assistant 贊教, and conversion preceptor 紀化 in order to systematically administer the well-known mountains, etc., within the empire. See the Jiaxing Edition of the Tripitaka, vol.21, p. 670.

16 See Ueda 2011, pp. 68-99.

17 For the course of the mission, see Song Lian, "Epitaph for the Burial Mound of Monk Yuanpu of Jiqing Teaching Temple in Kangzhou” 杭州集慶教寺原璞 法師璋公圓塚碑銘 (vol.2 of his Record of Protecting the Law) and “Sending Off Wuyi Keqin on His Visit to His Parents before Undertaking His Mission" 送無逸勤公出使還鄉省親序 (vol. 8 of his Record of Protecting the Law).

18 See Ueda 2011, pp. 188-190. 
If we compare the statements and actions of Song and Ming monks, we can see that Tianjie Chan Temple had indeed become more like a government agency by the Ming period, and that the monks of this temple had indeed become more bureaucratic. Yet the Central Buddhist Registry instituted at Tianjie Chan Temple was a government agency managing Buddhist monks throughout the nation. There are also other means to see how government temples became more like government agencies. Pursuing these hints will broaden our understanding of the bureaucratization of government temples during the Ming dynasty.

In “The Testing of Monks” 僧家考課 (volume 27 of Wanli ye huo bian), the Ming scholar Shen Defu 沈德符 (1578-1642), when discussing abbot vacancies in temples and monasteries of the two Ming capitals, mentions that monks were tested in assemblies by a director from the Ministry of Rites, that they were examined on their ability to write eight-legged essays 八股文, that those who performed well were selected to be abbots, that abbots were selected on their ability to write eight-legged essays without regard to seniority, education, or comportment, that abbots were ranked like officials, and that changes in positions in temples and monasteries were described as promotions, as in documents pertaining to personnel changes among officials. Shen Defu lived toward the end of the Ming dynasty, and he thus observed the temples and monasteries of the two Ming capitals to resemble government agencies. Very likely the development of this change began at the beginning of the Ming dynasty. Song Lian quite possibly was contrasting monks of Ming times, who had engrained in them bureaucratic tendencies typified by the Central Buddhist Registry, with the monks of government temples during Song and Yuan times.

\section{The Flow of Information between China and Japan during the Song and Yuan Dynasties}

There are temporal inconsistencies between Song Lian's two memorial inscriptions and the time when the Five Mountains were established. Though later scholars did not accept the view that the Five Mountains were established after the Song dynasty fled south, their views are consistent with this view. Ninkū Jitsudō 仁空実導 (1309-1388), a Japanese monk of Jōdō Sect 淨 土宗, West Mountain School 西山派, in his New Precepts for Study and Comportment 新學行要鈔, mentions that the Southern Song emperor Gaozong 高宗 (r. 1127-1162) set up meditation, teaching, and discipline temples, and that for each type of temple he instituted the Five Mountain, Ten Monastery system. ${ }^{19}$ Since this is the first mention that the three types of temples each

19 Taishō Revised Tripitaka, vol. 74, p. 785. For portions of the Taishō Revised 
instituted the Five Mountain, Ten Monastery system, we can surmise that the system began during the reign of Emperor Gaozong.

Though prior to Song Lian there was no mention of which temples the Five Mountains included or the order of their ranking, Zhou Mi, in "Yan Temple” 閻寺 (in his Miscellaneous Observations from Guixin Street, volume 2 of the supplemental collection 別集), recounts how the Emperor Lizong built the Gongde Monastery 功德院 for his Honored Consort Yan. In this account, he mentions all the benefits that the emperor conferred on Yan Temple: "For the Five Mountains before him, nothing was out of the question." 20 The "Five Mountains before him" refers to Jingci Temple 淨慈寺, Lingyin Temple 靈隱 寺, and the three Tianzhu Temples 天竺寺, all five of which were in Hangzhou. The Ming writer Shen Defu, in his "Testing of Monks," confirms this reference. ${ }^{21}$ Zhou Mi (1232-1298) lived during the late Song and early Yuan dynasties. When a writer of the time writes about a matter of his own time, it stands to reason that what he writes is accurate. Well, in that case, the term "Five Mountains," during the late Song period, referred, it would appear, to the five great monasteries in Hangzhou.

Moreover, the Japanese monk Kūkoku Myōō 空谷明應 (1327-1407), in volume 1 of Quotations of Jōkō, Preceptor of the Realm [i.e., Kūkoku Myōō] 常光國師語錄, recorded that Fan Zhongyan 范仲淹 recommended Chan Master Chenggu 承古 as the resident head of Jianfu Temple 薦福寺, in Raozhou, Jiangxi Province. He noted that Suzhou had Five Mountains, and that Jianfu Temple was originally ranked third among them, but after Chan Master Chenggu became the resident head of the temple, it became ranked as number one. ${ }^{22}$ Kūkoku Myōō, after becoming a monk, studied under Musō Soseki 夢窗疎石 (1275-1351) and, in terms of renown, is often mentioned with Zekkai Chūshin 絕海中津 (1336-1405). When he obtained his information, Suzhou, during the Northern Song period, already had five temples known as the Five Mountains, and Jianfu Temple in Raozhou had risen in rank from number three to number one. One can see that, though he was a little off as far as places were concerned, reports reaching Japan at the time were different from Song Lian's information. It thus seems that prior to the end of the Yuan dynasty, Suzhou and Hangzhou both had five temples known as the Five Mountains.

The earliest reference to the Five Mountains nearly as it is presently

Tripitaka about Japanese Buddhism, I referred to the SAT Saizōkyō Text Database (http://21dzk.1.u-tokyo.ac.jp/SAT/).

20 Zhou Mi 1988, p. 295

21 Shen Defu 1959, p. 688.

22 Taishō Revised Tripitaka, vol.81, p.21. 
conceived occurs in the conversation between Gidō Shūshin and Ashikaga Yoshimitsu. The three Tianzhu Temples were excluded from the Five Mountains, and in their place appeared Jingshan Temple in Hangzhou, Tiantong Temple in Mingzhou 明州, and Ayuwang Temple in Mingzhou. There is no question that Jingshan Temple should be included in the designation, but why were two temples of Mingzhou included? Mingzhou is the present-day city of Ningbo. Japanese monks coming to Song or Yuan China left Hakata in Kyushu by ship and first entered China at Ningbo. Hence, Ningbo is no less important than Hangzhou. In its intercourse with Song China, Japan first recognized Ayuwang Temple late in the Heian period (794-1192). For instance, the general Taira no Shigemori (1138-1179) sent the monk Myōden to Mingzhou to donate gold to Ayuwang Temple. During the Kamakura period, Minamoto no Sanetomo 源實朝 (1192-1219) sent a large ship to visit this temple. As for Tiantong Temple, it was the first temple at which Japanese monks stayed. For example, Eisai 笨西 (1141-1215) entered Song China to study under Chan Master Xu' an Huaichang 虛庵懷敞 at Tiantong Temple, and Dōgen 道元 (1200-1253) also studied at Tiantong Temple, under Tiantong Rujing 天童如淨 (1163-1228). Numerous Japanese monks spent time at Mingzhou. Hence, we can infer that the two temples at Mingzhou were more important than the three Tianzhu temples. ${ }^{23}$ In addition, the painting Famous Monasteries of the Great Song Empire 大宋名藍圖, painted by a Japanese monk during the Jiading era (1208-1224) of Emperor Ningzong's reign, includes Jingshan Temple, Lingyin Temple, and Jingci Temple in Hangzhou; Tiantong Temple and Ayuwang Temple in Mingzhou; Jinshan Temple 金山寺 in Zhenjiang; and Daochang Temple 道場寺 in Heshan, Huzhou. ${ }^{24}$ Such

23 See Kimiya 1977, pt. 4, "Southern Song and Yuan Dynasties," chap. 2, "Monks Entering Song China, Monks Settling in Song China, and the Transmission of Culture” 入宋僧・歸化宋僧と文化の移植, pp. 334-362.

24 This painting is also called Illustrated Explanation of the Five Mountains of the Great Song Empire 大宋五山圖說, but in addition to the Five Mountains, the painting also depicts Jinshan Temple in Zhenjiang, Bishan Temple 碧山寺 in Mingzhou, and Wannian Temple 萬年寺 on Mt. Tiantai. Hence, using the name Famous Monasteries of the Great Song Empire is more appropriate. The text in the painting has been thought to be composed by Dōgen, Enni 圓爾, or Gikai 義介, but since the text contains a reference to the painting Years of Ordination 夏臘圖, which is recorded as having been composed sometime during the Jiading period (1208-1224), we can eliminate Dōgen and Enni. Scholars have yet to agree on whether Gikai painted this work. On the date of the text, see Shimizu Kunihiko 清水邦彥, “A Study of Five Mountains and Ten Monasteries, Held by Daijō Temple” 大乘寺藏「五山十刹圖」考, Hikaku minzoku kenkyū 23 (2009), no. 3: 152-160. For the text itself, see Lan Jifu 1990, pp. 589-592. 
changes in the composition of the Five Mountains provides evidence that there were repeated vicissitudes in the prestige of temples during the Song and Yuan dynasties, although these changes were also viewed differently from the different perspectives of Chinese and Japanese observers.

From the news it received in interactions with China, the Japan side developed two different views. Kokan Shiren 虎關師鍊 (1278-1346) said that the monks of Lingyin Temple met in the Zhizhi Hall and decided on the ranking of the Five Mountains. Now, Lingyin Temple was always ranked below Jingshan Temple. Why would the monks of Lingyin Temple decide the ranking of the Five Mountains? Mujaku Dōchū thought that since Lingyin Temple was within the city of Hangzhou, Jingshan Temple was outside of the city, and Lingyin Temple was close to the imperial residence, it was natural for Lingyin Temple to be given the right to determine the ranking. Mujaku Dōchū also gave an example. Though Shōkoku Temple, located in hills north of Kyoto, was ranked second among the Five Mountains, because it was the family temple of the shoguns of the Muromachi bakufu, who set up a prebend in the Rokuon building to manage the affairs of the Five Mountains, Shōkoku Temple was given the privilege of managing these affairs. ${ }^{25}$ Lingyin Temple had similar circumstances.

Though Kokan Shiren's view was not adopted later, the issue is why he used this information. Kokan Shiren had profound knowledge of literary Chinese and was the most Sinified Zen monk of his time. He studied Song Neo-Confucianism under Yishan Yining 一山一寧 (1247-1317), wrote a collection of poetry entirely in Chinese, and wrote the first Japanese collection of biographies of monks, An Account of Buddhism to the Genkō Era [1321-1324] 元亨釋書. When he met a Chinese monk coming from Yuan China to Japan, he would discuss with him Song culture and new scholarly trends, and he had extensive conversations with Sesson Yūbai 雪村友梅 (1290-1347). ${ }^{26}$ Yet for all of his knowledge about China and his many opportunities to converse with Chinese monks, Kokan Shiren never heard any news that Shi Miyuan proposed the Five Mountain, Ten Monastery system to the court.

What Kokan Shiren said appears in volume 1 of Mujaku Dōchū's Notes on the Manifestations of Zen. In this volume Mujaku Dōchū records Kokan

25 Mujaku Dōchū 1990, p. 39. Dōchū's quotation of the Kokan Shiren passage leaves doubts. According to the manner in which Dōchū quotes Kokan Shiren, the whole passage should be what he said, but Shōkoku Temple was established after Kokan Shiren. Hence, I think that the first half of the passage quotes Kokan Shiren and the second half is Dōchū's explication.

26 For two detailed discussions of Kokan Shiren, see Tamamura 2003, pp. 203-210, and Chisaka 2002, pp.61-99. 
Shiren's words and Song Lian's "Inscription for the Stupa in Which Jueyuan, the Fourth Chan Master of the Tianjie Temple, Was Interred," yet he omits Song Lian's "Inscription for the Stupa in Which Gufengde, Abbot and Chan Master of the Jingci Temple, Was Interred." By means of these editorial decisions, Mujaku Dōchū indicated that the latter work is not reliable, that is, that the view that Shi Miyuan proposed the Five Mountain, Ten Monastery system to the court is not credible.

Somewhat later than Kokan Shiren, Mugan Soō 夢笅祖應 (d. 1314) noted another view. In "On the Outstanding Mountains" 秀峰說 (in The Drought and Rain Collection 旱霖集), he stated that the Five Mountain system was established by Qian Chu 錢俶 (929-988), King of Wuyue 吳越, during the Five Dynasties period (907-960), and that later rulers continued it. ${ }^{27}$ Shun'oku Myōha 春屋妙范 (1311-1388), a disciple of Musō Soseki, also held the view that King Qian Chu established the Five Mountain system..$^{28}$ Mugan Soō once taught Kokan Shiren. In addition, he also studied the Confucian classics for over thirty years and later lectured on Mencius in Kyoto. As a student of Neo-Confucianism, he was held in high repute. In sum, the view of Mugan Soō and Shun'oku Myōha, that the Five Mountain system was already established in the Five Dynasties period, was relatively well accepted in Japan at that time. In the literature on Sino-Japanese interaction, there thus were two views as to the origin of the Five Mountain system, and neither of these views mentions Shi Miyuan.

Kokan Shiren's view that the monks of Lingyin Temple met and determined the Five Mountains was not accepted at the time, and the views of Mugan Soō and Shun'oku Myōha, which reach all the way back to the Five Dynasties period or the Northern Song period, seem too far back to be credible, but there are relevant sources. The Southern Song literatus Mou Yan 牟 鼔 (1227-1311), in "Inscription for the Stupa in Which the Chan Master Longyuan Was Interred” 龍源禪師塔銘 (in volume 24 of his Collection of Mou Yan's Works 牟氏陵陽集), wrote,

The Chan master's family was from Siming and Shouguo, but they moved to Kaishou. When the governor and son of Grand Councilor Shi met the master, the two of them got along very well. The governor gave up his temporary residence and together with the master went into busi-

27 Mugan Soō 1973, pp. 851-852.

28 "The one who originally instituted the Five Mountains in the empire was the king of Wuyue. Emperor Taizu of the Song did not change the system, and the great Yuan emperor also kept it" (Shun'oku Myōha, Quotations of Chikaku Fumyō, Preceptor of the Realm 智覺普明國師語錄, vol.3, in Taisho Revised Tripitaka, vol.80, p.666). 
ness selling rabbit garments. He said, "How nice if I could quietly live out my days in the temple at Siming." Before long, the seat at Daochang Temple fell vacant. The various mountains in Liangzhe nominated a horde of candidates, who came to the temple. For this mountain was a Tang monastery, and ever since the Xining era when the great poet $\mathrm{Su}$ Shi visited Daochang Temple and wrote a number of poems, its fame has been greater than the Five Mountains. ${ }^{29}$

Grand Councilor Shi was Shi Miyuan. Daochang Temple was located in Heshan. Though it has always been listed as one of the Ten Monasteries, according to this passage, after $\mathrm{Su}$ Shi published the poem "A Visit to Daochang Temple in Heshan” 遊道場山何山 during the Northern Song Xining era (1068-1077), the temple increased in estimation, even surpassing the Five Mountains in notoriety. Well, can we understand this passage as indicating that the notion of the Five Mountains already existed during the reign of the Northern Song emperor Shenzong (r. 1067-1085), and that Daochang Temple was among the Five Mountains?

During the Song and Yuan dynasties, the private sector in Japan had frequent contact with China, and numerous monks from the Japanese Five Mountains visited China. Eisai entered Song China twice. He first entered China in 1168 from Ningbo and went on a pilgrimage to Mt. Tiantai. He later entered China in 1187 and, owing to instability, only went to Mt. Tiantai. He studied Chan Buddhism under Chan Master Xu'an Huaichang at Wannian Temple and went with him to Tiantong Temple, where he entered the priesthood. After he returned to Japan, he established the Rinzai School 臨濟宗 of Buddhism. Eisai's disciple Dōgen in 1223 left Japan from Hakata and entered China at Ningbo. At Tiantong Temple he studied Chan Buddhism under Chan Master Tiantong Rujing, and he left us a vivid description of his conversations with his master, A Record from the Baoqing Era (1225-1227) 寶慶記, composed in what was already the reign of Emperor Lizong. Rujing could become the abbot of Tiantong Temple only with help from Shi Miyuan, and in A Record from the Baoqing Era, Dōgen records a conversation in which Rujing discussed the Five Mountains, but there is no mention that Shi Miyuan proposed the Five Mountain system to the court.

Moreover, when the Yuan court attacked Japan, the Kamakura bakufu organized prayer assemblies of monks to pray for the protection of Japan, and all over Japan, Song Chinese participated in such activities. Regardless of whether they came to Japan before or after the fall of the Song dynasty, these

29 Wenyuange copy of the Siku quanshu, vol. 1188, p. 217. 
Chinese united with the Japanese to resist the Yuan invasion..$^{30}$ This shows that even under conditions of war, interactions between Japan and China continued.

There were also Chinese who went to Japan to proselytize. For example, after Lanxi Daolong 蘭溪道隆 (1213-1278) arrived in Japan, Hōjō Tokiyori 北 條時頼 (1227-1263) recognized his talents and appointed him as founder 開山 祖師 of Kenchō Temple 建長寺 in Kamakura. Lanxi Daolong brought to Japan relevant Song books, monk discipline, and temple architecture. He thus had a profound influence on the development of Buddhism in Japan. For another example, Yishan Yining originally went to Japan under orders from Kublai Khan to encourage the Japanese to submit to the Yuan court, but he took advantage of the opportunity to remain in Japan to proselytize. He also introduced Neo-Confucianism to Japan. Thereafter, Neo-Confucianism gradually took root among Japanese monks.

There were also Japanese monks who went to Yuan China of their own accord to study. The first monk to study in Yuan China was Sesson Yūbai, a disciple of Yishan Yining. He stayed in China for twenty-three years, traveling to twelve provinces and writing "An Account of Carrying Out the Way" 行道記, about what he saw and heard in China. In his literary accomplishments, he was the equal of Yuan literati. ${ }^{31}$

Musō Soseki's disciple Gidō Shūshin and Zekkai Chūshin had great respect for Ming literature. Taking advantage of the fact that Zekkai Chūshin was being sent as an envoy to China, Gidō Shūshin asked Song Lian to write the gravestone epitaph for Musō Soseki. ${ }^{32}$ Gidō Shūshin's influence includes informing Ashikaga Yoshimitsu about the Chinese Five Mountain, Ten Monastery system, and suggesting that Yoshimitsu reorder the ranking of the Five Mountains and place Nanzen Temple in Kyoto over the Five Mountains.

As the above discussion clearly shows, though there was a brief war between China and Japan during the Yuan dynasty, generally speaking, throughout the Song, Yuan, and Ming dynasties, merchants and monks of the two countries were in continual contact. ${ }^{33}$ In view of Japan's ample opportu-

30 See Ihara 2009, chap. 4, “The International Aspect of Medieval Temples and the Diplomatic Efforts of Monks” 中世寺院の国際性と外交僧, pp. 189-195.

31 On Sesson Yūbai's experience in Yuan China, see Tamamura 2003, pp.369-374; Ono Katsutoshi, “A Japanese Monk in Fourteenth-Century Chang'an: Sesson Yūbai” 十四世に長安を踏んだ日本僧: 雪村友梅のことども, in Ono Katsutoshi Hakushi Shōju Kinenkai 1982, pp. 533-574; and Imatani 1994.

32 See Song Lian, "Epitaph for the Japanese Preceptor of the Realm Musō Soseki" 日本夢窗正宗普濟國師碑銘, in vol. 2 of his Record of Protecting the Law (Jiaxing Edition of the Tripitaka, vol.21, pp.628-629).

33 See Kimiya 1977, "Monks Entering Yuan China and the Transmission of 
nities for observing developments in China, if Shi Miyuan did indeed propose the Five Mountain, Ten Monastery system to the court, the Japanese would surely have mentioned that fact in their reports. To think otherwise defies common sense.

\section{Conclusion}

During the Song and Ming dynasties, Japan imported Chan Buddhism from China, copied its Five Mountain, Ten Monastery system, and sought to establish a base to transmit Chan Buddhism to the east. Japanese temples could foster a system in which they had power equal to that of the aristocracy and the military clans, they could create organizations of monk-soldiers, and they could develop centrally organized command structures. Chinese temples did not develop any of these structures. Thus, Japan consciously borrowed temple architecture, monastic discipline, Buddhist assembly rituals, etc., with the result that it seems that at this time China and Japan both had formally similar Five Mountain, Ten Monastery systems of government temples. However, these similar architectural styles, similar monastic disciplines, and meditative practices derived from the same tradition were structured differently and also functioned differently. It is correct to understand the Japanese Five Mountain, Ten Monastery system as a system of governmentlike agencies functioning in a bureaucratic manner. But Chinese government temples were different from government agencies, and Chinese monks were not the equivalent of bureaucrats.

From sources we can discern four views of the origins of the Five Mountain, Ten Monastery system: Mugan Soō's view that King Qian Chu established the system during the Five Dynasties period, Kokan Shiren's view that the monks of Lingyin Temple met and decided on the system, and Song Lian's views that the Southern Song emperor Gaozong established the system and that Shi Miyuan proposed the system to the Southern Song court. Yet because we have inadequate sources, we cannot arrive at a settled theory of the system's origin. This is the most reasonable conclusion to be drawn in assessing the information flowing between China and Japan during the Song and Yuan dynasties.

Current received opinion affirms that Shi Miyuan proposed the Five Mountain, Ten Monastery system to the Southern Song court, but this view appeared as late as the time of Song Lian. During the Song and Yuan dynasties, no sources said a word about Shi Miyuan's alleged proposal. The information flowing between China and Japan during the Southern Song period indicates that Japanese Chan monks at Five Mountain temples did not accept

Culture” 入元僧と文化の移植, pp.444-485. 
the view that Shi Miyuan proposed the Five Mountain, Ten Monastery system.

In medieval interaction between China and Japan, the Song and Yuan Five Mountain government temples had a profound influence on Japanese Five Mountain government temples. In modern interaction between China and Japan, Japanese Five Mountain temples have been linked with Song and Yuan Five Mountain temples. These Japanese Five Mountain buildings have been well preserved, but the Chinese Five Mountain buildings have been reduced to rubble - a vast difference. Because we lack adequate sources about the Song and Yuan Five Mountain system of government temples, scholars have used the Japanese system to reconstruct the Chinese system, and amid this work the view that Shi Miyuan proposed the system has reappeared. As mentioned above, there are four records of when the Five Mountain, Ten Monastery system was established, but nowadays one sees scholars discussing only the view that Shi Miyuan proposed the system. They turn a blind eye to records of the other three views. This is selective use of the evidence, and their conclusions are nothing more than the results of such selective use of the evidence.

In examining the flow of information between China and Japan, we see the influence that these two nations had on each other, but the view that Shi Miyuan's proposal to the Southern Song court was the beginning of the Five Mountain, Ten Monastery system is not serious scholarship. Rather, it is only the embellishment of a story about Shi Miyuan. There is still room for discussion of the origins of the Five Mountain, Ten Monastery system.

\section{References}

\section{In Chinese}

Cheng Tinggui 成廷珪 (14th cent.). Ju Zhuxuan shiji 居竹軒詩集 (Poems Composed While Living at Zhuxuan). Taipei: Taiwan Shangwuyin Shuguan, 1986. Included in the Wenyuange 文淵閣 copy of the Siku quanshu 四庫全書, vol. 1216 . Photographic reproduction, Taipei: Taiwan Shangwuyin Shuguan, 1986.

Lan Jifu 藍吉富, ed. Chanzong quansh $u$ 禪宗全書 (Complete Works on the Chan Sect of Buddhism), vol.94. Taipei: Wenshu Wenhua Youxiangongsi, 1990.

Lin Xiyi 林希逸 (1193-1271). Zhuxi Yanzhai ji shiyi gao xuji 竹溪虞齋集十一暮續集 (Eleven Additional Works by Lin Xiyi). In the Wenyuange 文淵閣 copy of the Siku quanshu 四庫全書, vol. 1185. Photographic reproduction, Taipei: Taiwan Shangwuyin Shuguan, 1986.

Liu Changdong 劉長東. Songdai Fojiao zhengce lungao 宋代佛教政策論稿 (Essays on Song Policies Pertaining to Buddhism). Chengdu: Bashu Shushe, 2005.

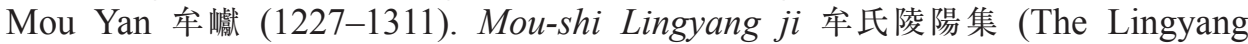
Collection of Mr. Mou's Works). In the Wenyuange 文淵閣 copy of the Siku quanshu 四庫全書, vol. 1188. Photographic reproduction, Taipei: Taiwan 
Shangwuyin Shuguan, 1986.

Shen Defu 沈德符 (1578-1642). Wanli ye huo bian 萬曆野獲編 (Matters Gleaned from Unofficial Sources during the Wanli Period [1573-1619]). Beijing: Zhonghua Shuju, 1959.

Song Lian 宋濂 (1310-1381). Hufa lu 護法錄 (Record of Protecting the Law). In Jiaxing cang 嘉興藏 (Jiaxing edition of the Tripitaka), vol.21.

Song Lian 宋濂 (1310-1381), ed. Yuan shi 元史 (A History of the Yuan Dynasty). Beijing: Zhonghua Shuju, 1976.

Xie Yingfang 謝應芳 (1296-1392). Guichao gao 龜巢稿 (Turtle Nest Compositions). In the Wenyuange 文淵閣 copy of the Siku quanshu 四庫全書, vol. 1218 . Photographic reproduction, Taipei: Taiwan Shangwuyin Shuguan, 1986.

Zhou Mi 周密 (1232-1298). Guixin zashi 癸辛雜識 (Miscellaneous Observations from Guixin Street). Beijing: Zhonghua Shuju, 1988.

\section{In Japanese}

Chikusa Masaaki 矢沙雅章. Chūgoku Bukkyō shakaishi kenkyū 中国仏教社会史研究 (Studies in the Social History of Chinese Buddhism). Kyoto: Dōhōsha Shuppan, 1983.

Chisaka Genpō 千坂浐峰. Gozan bungaku no sekai: Kokan Shiren to Chūgan Engetsu o chūshin ni 五山文学の世界: 虎関師錬と中嚴円月を中心に (The World of Five-Mountains Literature, with a Focus on Kokan Shiren and Chūgan Engetsu). Tokyo: Hakuteisha, 2002.

Ihara Kesao 井原今朝男. Chūsei juin to minshū 中世寺院と民衆 (Medieval Monasteries and the Masses). Enl. ed. Kyoto: Rinsen Shoten, 2009.

Imaeda Aishin 今枝愛真. Chūsei Zenshū shi no kenkyū 中世禅宗史の研究 (Studies in the History of Medieval Zen). Tokyo: Tōkyō Daigaku Shuppankai, 4th printing 2001.

Imatani Akira 今谷明. Genchō Chūgoku tokōki: Ryūgakusō Sesson Yūbai no sūkina unmei 元朝・中国渡航記: 留学僧・雪村友梅の数奇な運命 (Travelogue of a Trip to Yuan China: The Calamitous Adventure of Sesson Yūbai, a Monk Who Studied in China). Tokyo: Takarajimasha, 1994.

Ishii Shūdō 石井修道. “Chūgoku no gozanjussetsu seido no kisoteki kenkyū (ichi)" 中国の五山十刹制度の基礎的研究 (一) (Basic Research on the Chinese System of Five Mountains and Ten Monasteries, Pt.1). Komazawa Daigaku Bukkyō Gakubu ronshū 駒澤大学佛教学部論集, no. 13 (1982): 89-132.

Ishii Shūdō 石井修道. Sōdai Zenshū shi no kenkyū: Chūgoku Sōtōshū to Dōgen Zen 宋代禅宗史の研究: 中国曹洞宗と道元禅 (Studies in the History of Song Dynasty Chan Buddhism: Chinese Caodong Buddhism and Dōgen Zen Buddhism). Tokyo: Daitō Shuppansha, 1987.

Kamimura Kankō 上村観光, ed. Gozan bungaku zenshū 五山文学全集 (The Complete Works of Five-Mountains Literature). Kyoto: Shibunkaku Shuppansha, 1973.

Kimiya Yasuhiko 木宮泰彦. Nik-Ka bunka kōryūshi 日華文化交流史 (A History of Sino-Japanese Cultural Interaction). 5th ed. Tokyo: Fuzanbō, 1977.

Matso Kenji 松尾剛次. Kamakura shin Bukkyō no tanjō 鎌倉新仏教の誕生 (The Birth of New Forms of Buddhism in the Kamakura Period). Tokyo: Kōdansha, 1995. 
Mugan Soō 夢嚴祖応 (d. 1374). Kanrin shū 旱霖集 (The Drought and Rain Collection). In Kamimura 1973, vol.1.

Mujaku Dōchū 無著道忠 (1653-1744). Zenrin shōki sen 禅林象器箋 (Notes on the Manifestations of Zen). In Lan Jifu 1990, vol.96.

Ninkū Jitsudō 仁空実導 (1309-1388). Xin xuexing yaochao 新學行要鈔 (New Precepts for Study and Comportment). In Taishōzō 大正藏 (Taishō Tripitaka), vol. 74

Noguchi Zenkei 野口善敬. Gendai Zenshū shi kenkyū 元代禅宗史研究 (Studies in the History of Yuan Dynasty Chan Buddhism). Kyoto: Hanazono Daigaku Zen Bunka Kenkyūjo, 2005.

Ono Katsutoshi Hakushi Shōju Kinenkai 小野勝年博士頌寿記念会, ed. Tōhōgaku ronshū: Ono Katsutoshi Hakushi shōju kinen 東方学論集: 小野勝年博士頌寿記念 (Essays in East Asian Studies: Essays in Memory of the Long Life of Dr. Ono Katsutoshi). Kyoto: Ryūkoku Daigaku Tōyō Shigaku Kenkyūkai, 1982.

Shimizu Kunihiko 清水邦彦. “Daijō-ji zō 'Gozanjussetsu zu’ kō” 大乘寺藏「五山十 刹図」考 (A Study of the "Five Mountains and Ten Monasteries Painting" Held by the Daijō Temple). Hikaku minzoku kenkyu 比較民俗研究 23 (2009), no. 3.

Shunnoku Myōha 春屋妙范 (1312-1388). Chikaku Fumyō kokushi goroku 智覺普明 國師語錄 (Quotations of Shunnoku Myōha). In Taishōzō 大正藏 (Taishō Tripitaka), vol. 80 .

Tamamura Takeji 玉村竹二. Gozan Zensō denki shūsei 五山禅僧伝記集成 (Complete Biographies of Five-Mountains Zen Monks). Kyoto: Shibunkaku, 2003.

Ueda Jun'ichi 上田純一. Ashikaga Yoshimitsu to Zenshū 足利義満と禅宗 (Ashikaga Yoshimitsu and Zen). Kyoto: Hōzōkan, 2011. 